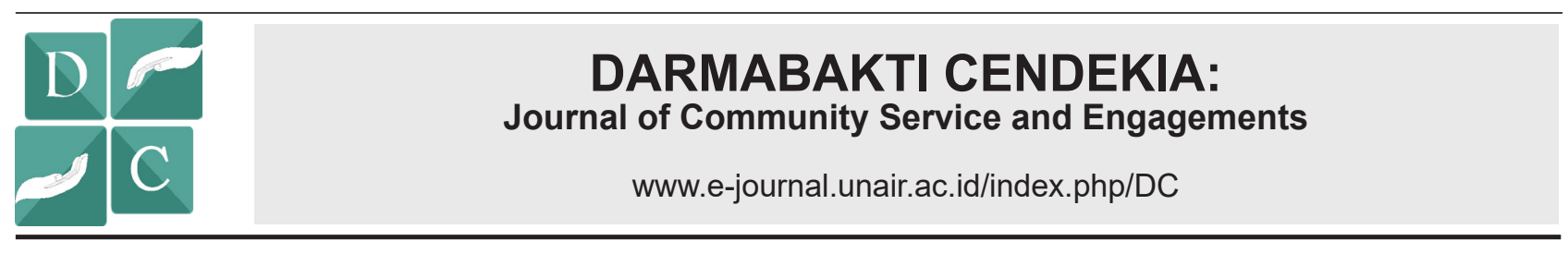

\title{
MANAGING THE POPULATION ADMINISTRATION SYSTEM OF SOKET LAOK VILLAGE, BANGKALAN, MADURA
}

\author{
PENATAAN SISTEM ADMINSTRASI KEPENDUDUKAN DESA \\ SOKET LAOK, BANGKALAN, MADURA
}

Scope:

Applied Science

\author{
Liestianingsih Dwi Dayanti*, Ratih Puspa, Rachmah Ida, Yuyun Wahyu Izati Suryd \\ Titik Puji Rahayu回 Nisa Kurnia Ilahiati, Angga Prawadika Aj@ \\ Department of Communication, Faculty of Social Science and Political Science, Universitas Airlangga, Surabaya-Indonesia
}

\section{A B S T R A C T}

Background: Unorganized population administration information system is the major problem in village administrations, including in Soket Laok Village, Bangkalan Regency. This unorganized system has impact on poor population and village economic potential data. This evidence becomes a major obstacle to improve community welfare and creates a significant setback in attempt to distribute any kind of assistance from the higher government. Therefore, it is necessary to organize a population administration system based on simple information technology and to improve the skills of village officials in fixing the population administration system. Purpose: To manage the village population administration system using simple information technology and to improve the skills of village officials in handling the population administration system. Methods: the method used in this program was a simple application of a population administration system based on Memento's digital app, which became the main focus in subsequent training session. The training was conducted in a form of webinars through the Zoom app and simple tutorials via YouTube. Results: the result of this activity is the availability of a population data collection system using the Memento application, a simple application that can be operated by village officials with a smartphone without an internet network in accordance with the conditions of Soket Laok Village which has not been evenly reached by the internet network. Another result is the increased skills of village officials in collecting population data using the Memento application. Conclusion: In this activity, village officials can have the skills to manage the village population administration system.

\section{A B S T R A K}

Latar Belakang: Sistem informasi administrasi kependudukan yang belum tertata dengan baik merupakan masalah yang banyak ditemui di pemerintahan desa termasuk Desa Soket Laok Kabupaten Bangkalan. Sistem yang belum tertata ini berdampak pada buruknya data kependudukan dan data potensi desa. Hal ini menjadi penghambat pembangunan kesejahteraan masyarakat dan penyaluran bantuan sosial dari pemerintah. Oleh karena itu diperlukan penataan sistem administrasi kependudukan berbasis teknologi informasi sederhana dan peningkatkan keterampilan perangkat desa dalam membenahi sistem administrasi kependudukan. Tujuan: Penataan sistem administrasi kependudukan desa dengan teknologi informasi sederhana dan peningkatan keterampilan perangkat desa dalam sistem administrasi kependudukan. Metode: Metode yang digunakan adalah pembuatan aplikasi sederhana sistem administrasi kependudukan berbasis teknologi digital Memento dan pelatihan keterampilan sistem adminsitrasi kependudukan dalam penggunaan aplikasi digital. Pelatihan dilakukan dengan webinar melalui aplikasi zoom dan tutorial melalui YouTube. Hasil: Hasil dari kegiatan ini adalah tersedianya sistem pendataan penduduk menggunakan aplikasi Memento, aplikasi sederhana yang bisa dioperasikan perangkat desa dengan smartphone tanpa jaringan internet sesuai dengan kondisi Desa Soket Laok yang belum terjangkau jaringan internet dengan merata. Hasil lain adalah meningkatnya keterampilan perangkat desa dalam melakukan pendataan penduduk menggunakan aplikasi Memento. Kesimpulan: Pada kegiatan ini, perangkat desa bisa memiliki keterampilan dalam mengelola sistem administrasi kependudukan desa.

\section{ARTICLE INFO}

Received 5 May 2021 Revised 3 September 2021 Accepted 21 October 2021 Online 10 November 2021

*Correspondence (Korespondensi): Liestianingsih Dwi Dayanti

E-mail:

liestianingsih.dwi@fisip.unair. ac.id

\section{Keywords:}

Population Administration Information System; Memento digital application; Population data arrangement

Kata kunci:

Sistem Informasi Administrasi Kependudukan; Aplikasi digital Memento; Penataan data kependudukan

Darmabakti Cendekia: Journal of Community Service and Engagements p-ISSN: 2657-201X; e-ISSN: 2657-1099 DOI: $10.20473 /$ dc.V3.12.2021.38-44

Open access under Creative Commons Attribution-Non Comercial-Share A like 4.0 International License

(CC-BY-NC-SA) (c) (B) (3) (2) 


\section{PENDAHULUAN}

Sistem administrasi kependudukan menjadi salah satu masalah yang dihadapi sebagian besar pemerintah desa di Indonesia. Persoalan yang mengedepan adalah kurang tertatanya sistem admistrasi kependudukan sehingga pemerintah desa tidak memiliki data kependudukan yang akurat. Ketiadaan data ini menyulitkan pemerintah desa dalam menyusun berbagai program pengembangan desa untuk menyejahterakan warga desa. Sistem administrasi kependudukan diatur dengan Permendagri No.95/2019 tentang Sistem Informasi Administrasi Kependudukan (SIAK) (Menteri Dalam Negeri Republik Indonesia, 2019). Ststem int mengatur pendataan penduduk berbasis teknologi informasi. Namun sistem ini belum menyentuh hingga pemerintahan terbawah yakni desa.

Salah satu desa yang belum memiliki sistem admisnitrasi data kependudukan adalah Desa Soket Laok, Kabupaten Bangkalan, Madura. Ketiadaan sistem administrasi ini menyulitkan pemerintah desa memetakan permasalahan desa. Dalam upaya membenahi sistem adminstrasi kependudukan tersebut Departemen Komunikasi FISIP Universitas Airlangga melakukan kegiatan pengabdian kepada masyarakat di Desa Soket Laok. Dalam kajian IImu Komunikasi pengabdian kepada masyarakat masuk dalam ranah Komunikasi Pembangunan. Perserikatan Bangsabangsa (PBB) menyebutkan bahwa praktik komunikasi pembangunan dimaknai sebagai:

"... a social process based on dialogue using a broad range of tools and methods. It is also about seeking change at different levels, including listening, building trust, sharing knowledge and skills, building policies, debating and learning for sustained and meaningful change. It is not public relations or corporate communications" (Thomas and Van De Fliert, 2015).

PBB membagi praktik Komunikasi Pembangunan menjadi empat aspek yaitu: (1) komunikasi dan perubahan perilaku,(2)komunikasi untuk perubahan sosial, (3) komunikasi untuk advokasi, dan (4) pemberdayaan dan penguatan lingkungan untuk meningkatkan media dan komunikasi(UNDP, 2011).

Praktik Komunikasi Pembangunan idealnya harus menerapkan prinsip-prinsip (1) dialog, (2) advokasi, (3) partisipasi, dan (4) tujuan (purpose) (Thomas and Van De Fliert, 2015). Dialog merujuk kepada praktik kommunikasi dua arah (two-way communication) di antara semua pemangku kepentingan. Komunikasi Pembangunan sangat ditekankan untuk menghindari bentuk-bentuk komunikasi satu arah (one-way communication), terlebih lagi model-model komunikasi yang bersifat top down (Dutta, 2011). Untuk advokasi, masyarakat lokal diharapkan dapat terberdayakan (empowered) dengan mengakui hak-hak mereka dalam memberikan masukan terhadap proses pembangunan itu sendiri (UNDP, 2011). Elemen ketiga, partisipasi adalah semua praktik komunikasi pembangunan membutuhkan partisipasi aktif dari semua pemangku kepentingan dalam setiap dan semua tahap yang dilalui untuk mampu mencapai perubahan sosial yang diinginkan dengan menerapkan pendekatan yang inklusif (Thomas and Van de Fliert, 2014).

Prinsip partisipatori diterapkan dalam kegiatan pengabdian kepada masyarakat di Desa Soket Laok, Kabupaten Bangkalan, Madura, yakni dengan pola kemitraan antara Departemen Komunikasi FISIP Universitas Airlangga dengan pemerintah Desa Soket Laok (FISIP UNAIR, 2020). Pengabdian dilakukan pada tahun 2020. Desa Soket Laok terletak tidak jauh dari kawasan Jembatan Suramadu dan berjarak 30 menit perjalanan dari Kota Surabaya merupakan salah satu desa tertinggal di Madura. Kondisi alam yang terdiri dari tanah tegalan, sebagian tanah keras yang tidak subur dan di musim kemarau kering menyebabkan terbatasnya tanaman pangan yang dihasilkan. Selain kondisi alam yang tidak subur, permasalahan yang mengemuka adalah belum tertatanyasistemadminsitrasikependudukan. Data kependudukan merupakan elemen penting dalam pengelolaan pemerintahan desa. Data ini menjadi indikator kondisi sosial, ekonomi dan potensi desa yang dapat digunakan untuk merancang program pembangunan untuk kesejahteraan masyarakat. Ketiadaan data ini menjadi salah satu sebab pemerintah desa kesulitan memetakan permasalahan dalam meningkatkan kesejahteraan masyarakat bahkan pemberian bantuan sosial dari pemerintah tidak merata dan tidak terserap maksimal. Persoalan lain yang ditemukan adalah rendahnya kesadaran warga akan pentingnya identitas kependudukan seperti Kartu Tanda Penduduk (KTP), Kartu Keluarga (KK), Akte Kelahiran, Akte Nikah. Warga desa tidak berminat melaporkan data diri untuk dicatat dalam sistem administrasi desa sehingga warga banyak yang tidak memiliki dokumen kependudukan. Ketiadaan dokumen ini menyulitkan warga dalam mengurus dokumen perjalanan, pernikahan, kematian dan lain-lain. Di sisi lain perangkat desa kurang memiliki keterampilan dalam mengelola sistem adminstrasi kependudukan.

Berkait dengan hal tersebut permasalahan yang menjadi fokus dalam pengabdian kepada 
masyarakat adalah pentingnya penataan sistem administrasi kependudukan berbasis teknologi informasi. Tujuan kegiatan adalah membenahi sistem administrasi kependudukan desa berbasis teknologi informasi dan meningkatkan keterampilan perangkat desa dalam mengelola sistem adminstrasi kependudukan berbasis teknologi informasi. Manfaat yang diharapkan adalah tersedianya sistem adminstrasi kependudukan berbasis teknologi informasi sederhana dan meningkatnya keterampilan perangkat desa dalam sistem adminsitrasi kependudukan desa.

\section{METODE}

Metode pegabdian kepada masyarakat dilakukan dengan beberapa langkah, pertama survei awal untuk mengumpulkan data. Survei dilakukan dengan observasi ke lokasi pengabdian masyarakat Desa Soket Laok dan mengadakan Focus Group Discussion (FGD) dengan Kepala Desa, perangkat desa, tokoh masyarakat serta Karang Taruna. Kedua, dari hasil observasi dan FGD tim melakukan identifikasi masalah untuk menentukan metode pemecahan masalah. Ketiga, dari FGD dan observasi tim menemukan bahwa sistem adminitrasi kependudukan Desa Soket Laok perlu dilakuan pembenahan dengan menggunakan teknologi informasi sederhana yang mudah diakses dan dioperasikan perangkat desa dengan menggunakan aplikasi digital Memento yang diakses melalui smartphone. Penggunaan aplikasi Memento karena smartphone saat ini telah banyak dimiliki perangkat desa dan penggunaan aplikasi ini tidak memerlukan sinyal internet. Untuk meningkatkan keterampilan perangkat desa dalam penataan sistem administrasi kependudukan khususnya dalam penggunaan aplikasi digital dilakukan pelatihan melalui aplikasi zoom dan pembuatan video tutorial dan diunggah di YouTube.

\section{HASIL DAN PEMBAHASAN}

Kegiatan pengabdian kepada masyarakat yang dilakukan oleh Departemen Komunikasi FISIP Universitas Airlangga di Desa Soket Laok, Kabupaten Bangkalan, Madura sebagai upaya implementasi teknologi informasi ke dalam sistem adminsitrasi pemerintahan desa. Hal ini sebagai bentuk penerapan SIAK (Sistem Informasi Administrasi Kependudukan) di tingkat desa. Saat ini sistem administrasi desa tidak bisa mengelak dari masuknya teknologi baru dengan praktik e-government. Kegiatan pengabdian masyarakat yang dilakukan memperkenalkan teknologi informasi kepada masyarakat desa meski dalam skala kecil dan sederhana berupa penataan sistem administrasi desa dengan teknologi digital.

Menurut (Miller, 2015), diterapkannya teknologi informasi baru dalam organisasi memiliki beberapa karakteristik (1) teknologi informasi baru memungkinkan transfer pesan lebih cepat dibandingkan dengan bentuk-bentuk komunikasi konvensional; (2) teknologi informasi baru memungkinkan komunikasi di antara para pelaku komunikasi yang tinggal berjauhan secara geografis; dan (3) teknologi informasi baru memungkinkan untuk terjadinya asynchronous communication sebuah kegiatan komunikasi yang berlangsung tidak secara real time atau terjadi dalam waktu yang berbeda di antara para partisipan komunikasi tersebut.

Fulk et al. dalan Miller (2015) menjelaskan bagaimana manusia beradaptasi terhadap implementasi teknologi informasi baru yang diterapkan di dalam organisasi dengan sebuah model yang disebut sebagai Social Information Processing Model of Media Use. Penggunaan teknnologi komunikasi baru di dalam organisasi kemungkinan besar dipengaruhi oleh hal-hal sebagai berikut: (1) apakah teknologi tersebut memungkinkan communication cues yang jelas (the richness of the medium); (2) kejelasan dari tugas-tugas yang diberikan oleh atasan; (3) nilai simbolik dari teknologi informasi itu sendiri; (4) seberapa mendesak keperluan bekerjasama dalam tim; serta (5) bagaimana informasi-informasi sosial yang diterima oleh para karyawan baik dalam konteks organisasi maupun di luar organisasi.

Hal ini menyulitkan pemerintah desa dalam menyusun program pembangunan. Seperti tertera dalam Undang-Undang Pemerintah Desa Nomor 6 Tahun 2014 pasal 1 (2) bahwa Pemerintahan Desa adalah penyelenggaraan urusan pemerintahan dan kepentingan masyarakat setempat dalam sistem pemerintahan Negara Kesatuan Republik Indonesia (Republik Indonesia, 2014) Desa memiliki kewenangan dalam penyelenggaraan pemerintahan, pelaksanaan pembangunan, pembinaan kemasyarakatan dan pemberdayaan masyarakat desa dengan melibatkan masyarakat. Pemerintah desa memiliki tanggung jawab untuk membangun desa dan menyejahterakan warganya.

Di era yang serba digital saat ini sistem administrasi kependudukan berbasis teknologi informasi merupakan tuntutan untuk mempermudah pengelolaan administrasi desa. Seperti telah diuraikan bahwa Desa Soket Laok belum memiliki data demografi yang akurat. Hal ini menjadi pangkal berbagai permasalahan desa seperti kesulitan dalam pengembangan desa 
dan menyejahterkaan warga. Menindaklanjuti hal tersebut tim pengabdian kepada masyarakat Departemen Komunikasi melakukan program dengan tujuan menyebarkan ide-ide baru, inovasi di bidang teknologi informasi dalam pendataan kependudukan. Penyebaran ide-ide baru sebagai upaya perubahan sosial. Dalam kajian ilmu Komunikasi, ada banyak cara untuk menyebarkan gagasan kepada orang lain seperti kampanye, komunikasi persuasif dan praktik social marketing atau komunikasi pemasaran sosial. Komunikasi pemasaran sosial pada awalnya mengakar pada kajian pemasaran yang digunakan dalam konteks bisnis dan perdagangan. Dalam perkembangannya, konsep ini perlahan bergeser dan diredefinisi menjadi praktik untuk peningkatan kemaslahatan masyarakat luas untuk tujuan-tujuan perubahan sosial. Sebagai sebuah 'alat' untuk memfasilitasi perubahan sosial dengan tujuan akhir terjadinya perubahan perilaku (behavior change) dalam masyarakat. Meski demikian tidak semua kegiatan komunikasi pemasaran sosial dilakukan untuk megubah perilaku secara cepat namun secara bertahap yang diawali dengan perubahan kesadaran, mengubah pengetahuan (awareness level) dan dilanjutkan dengan mengubah sikap (attitude level) baru perubahan perilaku menjadi tujuan akhirnya.

Menurut Donovan dan Henley (2010) untuk mengubah perilaku dalam masyarakat ada tiga hal penting yang perlu diperhatikan yaitu: (1) perlunya melakukan edukasi (to educate) berkaitan dengan aspek informasi dan keahlian (information and skills); (2) perlunya melakukan motivasi (to motivate) yang berkait dengan persuasi; (3) perlunya melakukan praktik-praktik advokasi (to advocate) yang berkaitan dengan tindakantindakan sosial politik (socio-political action).

Komunikasi pemasaran sosial meredefinisi konsep 4P (Product, Price, Place, Promotion) dari komunikasi pemasaran dan menyesuaikannya dengan tujuan komunikasi pemasaran sosial yang terkait dengan perubahan sosial dankemaslahatan (well-being) masyarakat lua\$. Donovan dan Henley (2010) menyebutkan 4P tersebut adalah:

1. Population prevalence adalah praktik komunikasi pemasaran sosial untuk mengubah masyarakat yang masih mempraktikkan perilaku/kegiatan/kepercayaan (beliefs) serta sikap yang merugikan/menghambat kesejahteraan hidup mereka dan menggantinya dengan perilaku-perilaku yang lebih baik.

2. Products and services adalah upaya komunikasi pemasaran sosial mencermati berbagai layanan dan produk-produk yang dikonsumsi oleh masyarakat yang berkontribusi terhadap terhambatnya pencapaian kesejahteraan hidup itu sendiri. Upaya komunikasi pemasaran sosial diharapkan tidak tinggal diam dan ikut melakukan upaya agar produk-produk yang merugikan masyarakat tersebut bisa diatur kembali peredarannya.

3. Places, komunikasi pemasaran sosial melakukan observasi tehadapat 'tempattempat' yang dekat dengan berkumpulnya masyarakat seperti rumah kediaman, sekolah, pasar, tempat-tempat peribadatan, dan sebagainya serta melakukan analisis apakah tempat-tempat tersebut berkontribusi terhadap pencapaian kesejahteraan masyarakat.

4. Political changes adalah upaya komunikasi pemasaran sosial diyakini tidak akan tercapai secara menyeluruh jika tidak adanya dukungan dan perubahan peraturan, kebijakan, dan regulasi-regulasi lainnya. Karena itu upaya komunikasi pemasaran sosial idealnya adalah sebuah upaya yang holistik dengan mengikutsertakan banyak pihak terkait ke dalam upaya-upaya perubahan sosial yang dilakukan menggunakan komunikasi pemasaran sosial tersebut.

Berkait dengan uraian tersebut, kegiatan pengabdian kepada masyarakat merupakan upaya melakukan perubahan pada sistem administrasi kependudukan desa. Kegiatan ini diharapkan mampu memberi efek ke arah perubahan masyarakat Desa Soket Laok yakni tumbuhnya kesadaran untuk memiliki identitas kependudukan, perubahan pada sistem adminisitrasi kependudukan dan meningkatnya keterampilan perangkat desa dalam mengelola administrasi kependudukan berbasis teknologi informasi.

Pengabdian kepada masyarakat dengan pola kemitraan yang dilakukan merupakan wujud dari praktik Komunikasi Pembangunan yang partisipatoris. Kegiatan ini terintegrasi dalam program pemerintahan desa untuk membenahi sistem administrasi kependudukan desa. Dengan kata lain kegiatan ini sejalan dengan pernyataan bahwa praktik komunikasi pembangunan harus terintegrasi ke dalam visi dan misi kepemimpinan dalam organisasi yang melakukan programprogram pemberdayaan tersebut (Van de Fliert, 2010) dan pentingnya berempati, memahami, dan kemampuan melihat permasalahan dengan meletakkannya pada konteks sosial yang berbeda-beda antara satu daerah dan daerah lainnya. Konsep 'partisipatoris' penting untuk terus dievaluasi dan dire-evaluasi terus, apakah program-program pemberdayaan yang dijalankan 
benar-benar berprinsip 'komunikasi partisipatoris' dengan masyarakat yang dibina atau belum, khususnya dalam kaitannya dengan pemahaman pihak 'donor' terhadap budaya dan adat setempat (Van de Fliert, 2010). Hal ini digarisbawahi oleh Van de Fliert dan Pham sebagai berikut:

"Voice, participation and ownership cannot be expected to materialize when the process trying to achieve that is enforced on prevailing social and governance structures that have no immediate interest in outcomes like empowerment. Consequently, processes to be applied and outcomes to be aspired need to be subject to negotiation, adaptation and compromise with the stakeholders who are expected to sustain those outcomes" dalam Thomas \& Van de Fliert (2014).

Untuk memahami tahapan bentuk-bentuk komunikasi partisipatoris, ada lima bentuk dan level pelibatan masyarakat (community engagement) yang menunjukkan partisipatoris dalam programprogram pemberdayaan masyarakat:

1. Konvensional: pihak donor (outsiders) membuat keputusan secara sepihak tanpa melibatkan pihak masyarakat yang dibantu, meski data dan informasi tentang itu ada dan bisa dipelajari.

2. Konsultatif: keputusan masih diambil secara sepihak oleh pihak donor meski telah melakukan upaya komunikasi dengan pihak masyarakat yang dibantu. Semua informasi dari masyarakat lokal dimaknai secara sepihak oleh pihak donor melalui komunikasi yang bentuknya hanya satu arah.

3. Kolaboratif: keputusan telah diambil secara bersama-sama antara pihak donor dan pihak masyarakat lokal. Kedua belah pihak saling mengetahui keinginan, kemauan, dan pendapat satu sama lain yang diperoleh melalui komunikasi dua arah.

4. Kolegial (collegial): masyarakat lokal membuat keputusan bersama setelah berkomunikasi dengan pihak donor. Masyarakat setempat memahami dan mengetahui keinginan dan pendapat serta saran dari pihak donor yang diperoleh melalui komunikasi dua arah. Keputusan masyarakat setempat tersebut bisa jadi atau tidak dipengaruhi oleh pendapat dan arahan dari pihak donor.

5. Keputusan secara lokal: masyarakat setempat membuat keputusan sendiri baik secara individual maupun kelompok tanpa melalui proses komunikasi formal dengan pihak donor. Mereka bisa saja berkonsultasi atau meminta pendapat kepada pihak donor, tetapi proses pengambilan keputusan tidak difasilitasi oleh pihak donor (Van de Fliert et al., 2010).

Dari kelima level tersebut, bisa dimaknai bahwa semakin kecil nomor level yang diterapkan maka semakin kurang partisipatoris aktivitas pemberdayaan yang dilakukan, sementara semakin besar nomor levelnya kegiatan pemberdayaan bisa dianggap lebih partisipatoris. Dalam praktik di lapangan tidak semudah itu dilaksanakan, karenanya untuk sebuah proses yang benarbenar ideal besar kemungkinannya kelima level tersebut diterapkan dan dijalankan dalam sebuah bentuk komunikasi yang terus berjalan secara sirkular. Berkait dengan kegiatan pengabdian kepada masyarakat Departemen Komunikasi, komunikasi partisipatoris dilakukan pada level ketiga dan keempat yakni kolaboratif dan kolegial (kemitraan). Program kegiatan direncanakan dan diputuskan bersama antara masyarakat desa yang diwakili perangkat desa dengan tim pengabdian kepada masyarakat Departemen Komunikasi. Hasil dari keputusan ini adalah penggunaan teknologi informasi digital untuk pendataan penduduk dan peningkatan keterampilan perangkat desa dalam mengelola sistem administrasi kependudukan melalui pelatihan.

Pembenahan sistem admisnitrasi kependudukan ini diharapkan di kemudian hari dapat mendukung pemerintah desa dalam mengembangkan Desa Soket Laok mengingat desa ini memiliki sumber daya alam yang potensial. Wilayah Desa Soket Laok terbagi dalam enam dusun dengan jumlah Kepala Keluarga 1041 dan jumlah penduduk 3967 jiwa. Kondisi alam yang kering menjadikan Desa Soket Laok termasuk desa teritnggal, padahal Desa Soket Laok memiliki sumber daya alam yang menjanjikan antara lain mente, singkong dan gadung. Namun potensi tersebut belum diolah secara optimal. Data potensi desa ini belum tercatat di pemerintah desa.

Dari pemetaan masalah tersebut kegiatan pengabdian kepada masyarakat melakukan program: pertama, membuat aplikasi digital Memento untuk pendataan penduduk. Aplikasi Memento merupakan teknologi informasi sederhana yang bisa diunduh menggunakan smartphone. Aplikasi ini dapat diperoleh dengan harga terjangkau, mudah digunakan tanpa memerlukan sinyal handphone dan terlebih saat ini smartphone sudah dimiliki oleh sebagian besar masyarakat. Melalui aplikasi ini dapat dilakukan pendataan status penduduk, identitas seperti nama, jenis kelamin, tanggal lahir, status perkawinan, agama, alamat, nama ayah dan ibu. Data lain adalah pendidikan, pekerjaan, penghasilan, asuransi kesehatan, penyakit yang 
diderita, kesehatan ibu, anak dan lansia, imunisasi, ibu hamil dan lain-lain. Keberadaan aplikasi ini otomatis akan menyediakan data desa secara komprehensif, sehingga memudahkan perangkat desa dalam mengelola sistem administrasi desa. Data penduduk dapat terintegrasi secara otomatis. Berikut gambaran aplikas digital Memento.

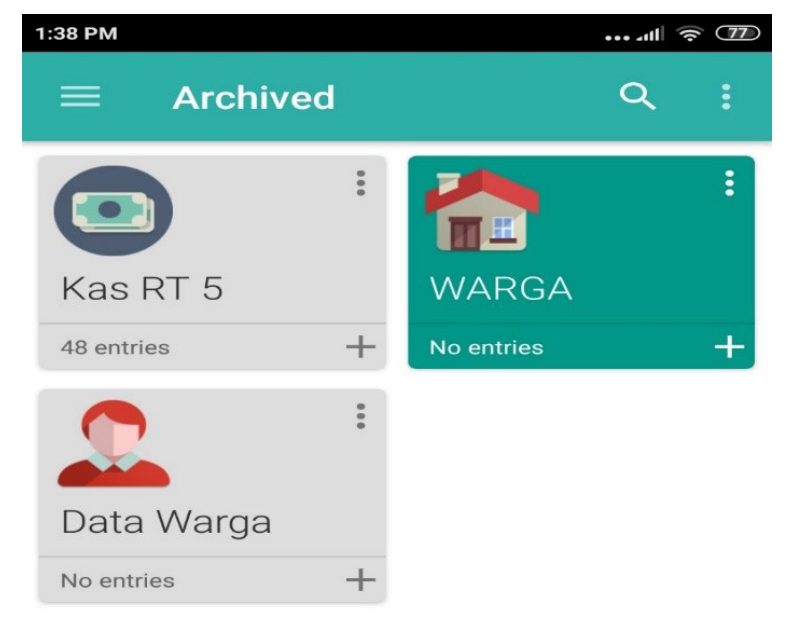

Gambar 1. Aplikasi Digital Memento Pendataan Pendudukan

Kedua, program peningkatan keterampilan perangkat desa dalam pembenahan sistem administrasi kependudukan desa serta penggunaan aplikasi digital Memento. Peningkatkan keterampilan dilakukan dengan memberikan pelatihan kepada perangkat desa melalui aplikasi zoom. Pelatihan diselenggarakan tiga kali dihadiri oleh Kepala Desa, perangkat desa, Kepala Dusun dan Karang Taruna. Pertemuan pertama membahas pentingnya pembenahan sistem administrasi kependudukan. Materi yang disampaikan adalah sistem administrasi yang tertata baik memudahkan desa dalam memetakan masalah dan potensi desa untuk menyusun program pengembangan desa. Dalam pertemuan tersebut disampaikan juga pentingnya data penduduk yang akurat dalam program bantuan desa, bantuan sosial, bantuan dampak Covid-19 dan bantuan lain dari pemerintah. Dalam pertemuan kedua, perangkat desa berlatih dalam mengidentifikasi permasalahan desa serta potensi yang dimiliki untuk dikembangkan sebagai aset bagi kesejahteraan warga. Pertemuan ketiga menjelaskan penggunaan aplikasi digital Memento untuk mendata penduduk. Dalam kegiatan pelatihan tersebut perangkat desa dan karang taruna mempraktekan cara mengunduh aplikasi, mengunggah data dan menyimpannya. Pertemuan ketiga membahas tentang pemetaan masalah dan potensi Desa Soket Laok.

Ketiga, untuk mempermudah pemahaman penggunaan aplikasi digital Memento, tim membuat video tutorial dan mengunggah di aplikasi YouTube. Video tutorial ini memudahkan perangkat desa dalam menggunakan aplikasi digital Memento. Video menjelaskan langkahlangkah dalam menggunggah data warga. Video dapat diakses melalui link https://youtu.be/ZRjqeowD30.

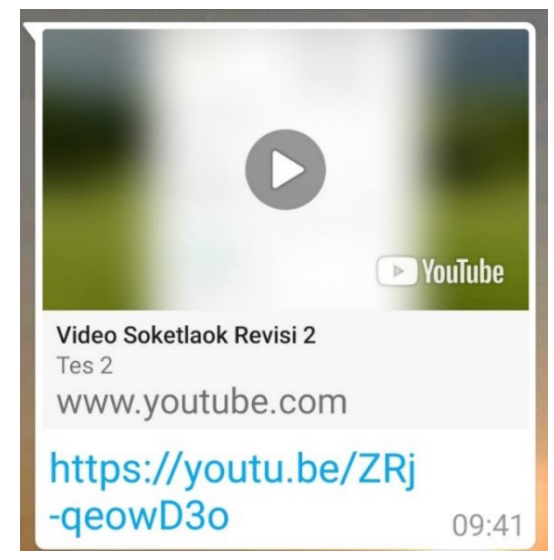

Gambar 2. Tutorial Penggunaan Aplikasi Digital Memento Via Youtube

Pandemi Covid-19 mengubah kegiatan pengabdian kepada masyarakat yang awalnya akan dilakukan pendampingan langsung secara tatap muka menjadi kegiatan daring menggunakan internet. Namun hal ini tidak mengurangi semangat tim untuk membantu memecahkan masalah Desa Soket Laok dan mendorong tim berupaya mencari alternatif metode pengabdian dengan menggunakan aplikasi zoom. Hasil lain yang patut dicatat adalah penggunaan aplikasi digital Memento dalam pendataan penduduk di tingkat desa merupakan yang pertama dan satusatunya yang digunakan di Kabupaten Bangkalan.

\section{KESIMPULAN DAN SARAN}

Kegiatan pengabdian kepada masyarakat Departemen Komunikasi FISIP Universitas Airlangga di Desa Soket Laok, Kabupaten Bangkalan, Madura dilakukan tahun 2020. Kegiatan ini merupakan kerjasama antara Pemerintah Desa Soket Laok dan Departemen Komunikasi. Kegiatan diawali dengan survei awal untuk mendapatkan data dan memetakan permasalahan. Permasalahan yang mengemuka adalah Desa Soket Laok tidak memiliki sistem administrasi kependudukan yang akurat, bahkan sebagian besar warga tidak memiliki dokumen kependudukan seperti KTP, Kartu Keluarga, Akte Kelahiran, Akte Nikah dan lain-lain. Permasalahan lain adalah perangkat desa kurang memiliki keterampilan dalam mengelola sistem administrasi kependudukan desa. Dengan permasalahan tersebut kegiatan pengabdian 
kepada masyarakat melakukan program pembenahan sistem administrasi kependudukan berbasis teknologi informasi menggunakan aplikasi digital Memento sebuah aplikasi sederhana menggunakan smartphone untuk pencatatan data penduduk. Kegiatan lain adalah pelatihan keterampilan perangkat desa dalam menggunakan aplikasi digital Memento dan sistem administrasi kependudukan. Pelatihan dilakukan melalui aplikasi zoom. Selain itu tim menyusun video tutorial penggunaan aplikasi Memento yang diunggah melalui YouTube. Penggunaan teknologi informasi digital Memento dalam pendataan pendudukan merupakan yang pertama dan satusatunya di tingkat desa di Kabupaten Bangkalan.

Rekomendasi, kegiatan pengabdian kepada masyarakat yang seharusnya dilakukan pendampingan secara langsung namun karena pandemi Covid-19 maka kegiatan dialihkan dengan menggunakan media internet. Diharapkan kegiatan pengabdian kepada masyarakat dapat dilanjutkan secara langsung seusai pandemi. Di samping itu dari pemetaan potensi desa, Desa Soket Laok memiliki hasil pertanian berupa mente, gadung, ketela jika didayagunakan dengan optimal dapat meningkatkan perekonomian warga desa. Untuk itu perlu pendampingan dari dinas terkait.

\section{UCAPAN TERIMA KASIH}

Terima kasih disampaikan kepada Kepala Desa Soket Laok, Kabupaten Bangkalan Madura berserta perangkat desa, tokoh masyarakat dan masyarakat Desa Soket Laok yang menjadi mitra dalam kegiatan pengabdian kepada masyarakat. Terima kasih disampaikan atas dukungan penuh kepada tim pengabdian kepada masyarakat Departemen Komunikasi FISIP Universitas Airlangga sehingga kegiatan dapat terlaksana dengan lancar. Penulis menyatakan tidak ada konflik kepentingan dengan pihak-pihak yang terkait dalam kegiatan pengabdian kepada masyarakat ini.

\section{DAFTAR PUSTAKA}

Donovan, R., \& Henley, N., 2010. Principles and practice of social marketing: an international perspective. Cambridge University Press, Cambridge.
Dutta, M.J., 2011. Communicating social change: structure, culture and agency, 1st ed. Routledge, New York.

FISIP UNAIR, 2020. Aktualisasikan Pengabdian Masyarakat, Fisip Unair Tandatangani Memorandum of Agreement (MoA) Desa Binaan dengan Desa Soket Laok [WWW Document]. URL http://fisip.unair.ac.id/ kerjasama/read/1259/aktualisasikanpengabdian-masyarakat-fisip-unairtandatangani-memorandum-of-agreementmoa-desa-binaan-dengan-desa-soket-laok (diakses 3.19.20).

Menteri Dalam Negeri Republik Indonesia, 2019. Peraturan Menteri Dalam Negeri Republik Indonesia Nomor 95 Tahun 2019 Tentang Sistem Informasi Administrasi Kependudukan.

Miller, K., 2015. Organizational communication: Approaches and processes, 7 th ed. Cengange Learning, Stamford.

Republik Indonesia, 2014. Undang-Undang Republik Indonesia Nomor 6 Tahun 2014 Tentang Desa.

Thomas, P.N., Van de Fliert, E., 2014. Interrogating the Theory and Practice of Communication for Social Change: the basis for a renewal. Palgrave Macmillan, Basingstoke.

Thomas, P.N., Van De Fliert, E., 2015. Interrogating the Theory and Practice of Communication for Social Change: The Basis For a Renewal. Palgrave Macmillan, London.

UNDP, 2011. Communication for Development: Strengthening the effectiveness of the United Nations. United Nations Development Programme, New York.

Van de Fliert, E., 2010. Participatory communication in rural development: What does it take for the established order? Ext. Farming Syst. J. Vol. 6(1), Pp. 95-99.

Van de Fliert, E., Thi Vuong, P., Thi Minh Hien, D., Thomas, P.N., Nicetic, O., 2010. Out of comfort zones, into realities: Research for development with upland ethnic minority communities in North West Vietnam. In: Darnhofer, I., Grotzer, M. (Eds.), Proceedings of the 9th European IFSA Symposium. Universität für Bodenkultur Wien, Vienna, Pp. 330-342. 